\title{
Aggregate remittance cost and diaspora financing of overseas Filipino teachers in the kingdom of Thailand
}

\author{
Domingo T. Balse, Jr * \\ Kwong Chow School, Bangkok, Thailand
}

\section{Keywords \\ Cost accounting \\ Diaspora financing \\ Remittance cost}

Received: 9 August 2018

Accepted: 17 September 2018

Published: 10 October 2018

\begin{abstract}
The fundamental of this research is centered on determining the aggregate remittance cost and diaspora financing of Overseas Filipino Teachers (OFTs) in the Kingdom of Thailand. The Philippines is second to India with the highest total remittances from 1995-1999 (Gammeltoft, 2002). Given that the Philippines ranks second in terms of remittances, the researcher is interested in determining the aggregate cost of sending remittances to the Philippines and proposing the most cost-efficient and cost-effective remittance service provider. This is a related study to the previous research on Working Capital Management Practices of OFTs presented in Johor Bahru, Malaysia, in 2017. The researcher employed descriptive and comparative research using a mixed-method - partly quantitative and qualitative to address the problem's statement. In "descriptive research, it involves collecting information through data review, surveys, interviews, and observation" subjected for a data analysis (Kefela, 2011). The researcher used a survey questionnaire and interview schedule in obtaining information relevant to this study. Primary data were provided by the OFTs who are legally teaching in Thailand for at least one year. There were 120 plus OFTs surveyed and interviewed, but only 53 were qualified respondents because they were out of scope and delimited from this study. Secondary financial data were also utilized. One of the momentous findings in this study is the significant switch of OFTs just recently regarding their preferred remittance service provider. Ria remittance becomes the most preferred remittance agent of OFTs. Ria, a money transfer company, has recently partnered with the Government Savings Bank (GSB) in Thailand. Ria offers a cost savings of more than $50 \%$ compared to prominent remittance agents such as the Western Union (WU). Ria and Money Gram both charge $B 150.00$ per transaction. However, Ria offers a higher exchange rate. The study also revealed that $69.82 \%$ of the OFTs have a salary range of $B 20,000$ to $B 30,000$ and cash remittance ranges from $B 5,000$ to $B 15,000$ which is $25 \%$ of their salary. Policymakers of the Philippine government are encouraged to revisit the current financial literacy programs concerning OFWs in general. Further study may deal with WU and other remittance agents' threats resulting in the partnership of Ria Remittance with GSB.
\end{abstract}

(C) 2018 The Author(s). Published by TAF Publishing.

\section{INTRODUCTION}

Cash remittances play an essential role to OFWs worldwide. These diaspora financing flow alongside with the projected "average income and savings rates of OFWs are the primary factors in the size of the prospective market for migration investment products". According to a study, "the poorest migrants, on average, experienced a 15 -fold increase in income" which "is twice of school enrollment rates and a 16-fold reduction in child mortality after moving to a country (Kaplan, 2011)" normally "with higher standards of living than their home countries". Based on the study, "the top five were the Philippines $(14,830)$, Malaysia $(2,924)$, Singapore $(2,034)$, Myanmar $(1,948)$ and Indonesia $(1,279) "$. So, with Philippines (roughly 15,000 workers) compared to next- ranked Malaysia (roughly 3,000) there are roughly five times as many skilled Philippine migrants legally working in Thailand than from any other Asean country.

Diaspora financing takes a substantial portion of monetary inflows to developing countries like the Philippines. According to World Bank Report (2015), "and this exceed by three times the sum spent on Official Development Assistance" (ODA) and "rivals total Foreign Direct Investment

${ }^{*}$ corresponding author: Domingo T. Balse, Jr

†email: domingo_balse@yahoo.com 
(FDI) in developing countries wherein the top receivers are India (US\$63 billion), China (US $\$ 61$ billion), the Philippines (US $\$ 30$ billion) and Mexico (US $\$ 29$ billion)". It is not surprising for India and China to be top receivers of remittances knowing that these countries have the biggest population in the world. However, the Philippines is not that bigwhen it comes to population compared to China and India but it is comparable with respect "to the number of migrant workers" as well as cash remittances sent in its homeland. Monetary crisis in developed countries did not really affect the Philippine economy. There was "an economic miracle happened in the Philippines but this time hardly anyone noticed it and millions of Filipinos abroad keep sending a recorded number of remittances back to the Philippines despite the worldwide economic recession" (Asis, 2010; Yoo, Lee, \& Lee, 2016) which did not significantly impact its economy. Asis (2010) pointed out that "in March 2010 alone, the Filipino diaspora sent a total of US $\$ 1.55$ billion back home and these massive injections of remittances were mostly used for personal consumption". In addition, "it inadvertently buoyed the Philippine economy to avoid a deep recession thereby preventing the current, grinding poverty to become even worse". However, reducing the aggregate remittance cost of transferring money to the Philippines remains a big challenge to many OFWs worldwide and at the same time allotting savings and investment out of these cash remittances.

The World Bank's "Sustainable Development Goal (SDG) target is only 3 percent of cash remittances sent to the migrant's home country". However, few remittance service providers are charging more than this allowed percent.Western Union, MoneyGram, and Ria are notably dominating the global remittance industry based on "the market research by SaveOnSend.com wherein it is estimated that Western Union, Moneygram, and Ria together account for more than 25 percent of the global remittance volume (with Western Union accounting for about 13 percent)" making Western Union the top leader in this industry.

\section{Statement of the Problem}

The fundamental of this research is centered on determining the aggregate remittance cost and diaspora OFTs in Thailand. The Philippines is second to India with the highest total remittances from 1995-1999 (Gammeltoft, 2002). Given the fact that the Philippines ranks second in terms of remittances, the researcher is interested in determining the aggregate cost of sending remittances to the Philippines. This is a related study to previous research on Working Capital Management Practices of OFTs which was presented in
Johor Bahru, Malaysia in 2017. Ahsan (2014) revealed that "the Philippines has mandated prospective migrants not to accept wages lower than the prevailing minimum for the same skills in the host country, unless specified in a bilateral labor agreement or international convention that the host economy is a signatory". In addition, "the United States Department of States (2017) reported that most migrants entering Thailand did not use the formal mechanism due to high costs linked to corruption on both sides of the Thai border, lack of information, lengthy processing times and difficulties in changing employers". Some of these migrants are from the Philippines entering the Kingdom as tourists and later on look for jobs. With all these struggles working in the Kingdom, OFWs have to choose the best remittance agent that is the most cost-effective thereby increasing the money remitted and hopefully allots savings and diaspora investment from these cash remittances.Teachers from the Philippines working in Thailand are paid lower than OFTs "in the middle East, Africa, and in the United States of America". OFTs in Thailand are only paid an average range of US\$700 - US $\$ 1,000$ monthly which is only one-third if they teach in other countries. However, Thailand has the lowest cost of living and the culture is similar to the Philippines. In addition, OFTs can do part-time tutorial jobs and some OFTs are using their Thailand teaching experience as a stepping stone to eventually work in Western countries. Nonetheless, OFTs have to send their money with the most costeffective remittance service provider.

\section{Significance of the Study}

The current study primarily aims to provide the best remittance agent by conducting a comparative analysis of aggregate remittance cost so that OFWs working in the Kingdom of Thailand can maximize their cash remittances to the Philippines. The primary beneficiary of this study is the OFWs and their families in the Philippines and policy makers as secondary beneficiaries. Policy makers of the Philippine government may utilize this study as a tool in planning and implementing a more appropriate and more relevant financial literacy program thereby improving the scope of its regulations and policies concerning OFWs and their diaspora financing.

\section{Research Objectives}

The research attempts to determine the aggregate remittance cost and diaspora financing of OFTs in the Kingdom of Thailand with the following purposes:

1. To compare aggregate remittance cost from top remittance service agents thereby providing a "more cost- 
efficient and accessible financial transfer mechanisms to the Philippines".

2. To provide policy makers of the Philippine government a more relevant and useful program for OFTs in managing their finances in both the host and home countries.

\section{Research Questions}

Below are research questions which are central to this study:

1. What is the best remittance service provider from the top global leaders in the remittance industry in the Kingdom of Thailand?

2. How much is the aggregate remittance cost from the top remittance service providers in the Kingdom of Thailand using Activity-Based Costing (ABC)?

3 . What is the allocation of cash remittances in their expenditure items in the first-two years of teaching in the Kingdom of Thailand?

\section{LITERATURE REVIEW}

There is inadequate practical literature and studies on the recurring activities of diaspora financing and cash transmittals. In the studies of Frankel (2011) and Bettin, Lucchetti, and Zazzaro (2012), they have postulated that diaspora remittances "are largely altruistic and countercyclical with respect to the recipient economy" which is especially true for developing countries like the Philippines. However, "other studies have challenged these results and have reported that the investment-driven, procyclical tendency may be more prevalent (Giuliano \& Ruiz-Arranz, 2009; Hoai \& Thanwadee, 2015; Lueth \& Ruiz-Arranz, 2008)". In addition, "Durdu and Sayan (2010) documented that, whereas countercyclical remittances flows can mitigate macroeconomic volatility, procyclical flows have the potential to deepen it and the behavior of remittances during episodes of high macroeconomic volatility during current account reversals and financial crises, and their potential to stabilize consumption in response to income shocks, remain understudied in the literature". Thus, with inadequate practical literature "on the dynamic patterns of remittances", the researcher pose some questions.

World Bank Report (2015) cited in their report that "remittance transactions are known to be expensive, with estimates averaging 10 percent of the amount sent and there is a wide variation in these costs across corridors, ranging from 2.5 percent to 26 percent of the amount sent well above the SDG target of 3 percent" in most remittance service providers. J. Gibson, McKenzie, and Rohorua (2006) posited "that remittances flows are very sensitive to costs and are likely to increase significantly as costs go down" but even though cash remittances not only to the Philippines but in general is inelastic to cost, it would be better if aggregate cost of remittance can be reduced so that migrant workers can send more money to their home countries.

Financial education and "cash management literacy is becoming increasingly important in empowering migrants and also their dependent loved ones" in the Philippines to strengthen the monetary controlling capacities of OFWs thereby achieving financial independence. Financial literacy enables them in knowing in terms of economic and monetary decision-making, "develop awareness of personal financial issues and choices, and learn basic skills related to earning, spending, budgeting, saving, borrowing, and investing money" (Kefela, 2011). It is good to know that government banks in some Asian countries have encouraged migrants to send their "remittances through formal channels to better monitor the flow of money into the economy". For instance, the Central Bank of the Philippines has encouraged commercial banks to provide migrant workers information on opening bank accounts to access cheaper, easier, and safer money wiring services (Agcaoili, 2016).

Ashraf, Aycinena, Claudia, and Yang (2015) have studied on diaspora savings and revealed that emigrants "who had the most information about savings in their home country tended to have higher amount of savings than those who had less information and control".

Ashraf et al. (2015) noted that, "if migrants do not share the same financial objectives" with their households back in the Philippines, "information asymmetries may prevent migrants from achieving objectives that require the assistance or participation of relatives remaining in the home country". Further study of J. D. Gibson and McKenzie (2012) noted that after conducting financial literacy seminars on various remittance channels and costs among Pacific Island immigrants in New Zealand, "simple financial education training for migrants can change their knowledge about the costs of remitting" thereby this "lead them to look around more at prices". Consequently, "on-site training can also impart some necessary information to migrants".

It is important that the content of financial literacy programs should be considered, in those topics on "how to save" may be more important than "how to remit" (Cebeci, 2016; Doi, McKenzie, Zia, et al., 2012). Furthermore, it terms of cash remittances, "studies have suggested that migrants often consider perceived costs, personal characteristics, convenience, and availability of options as well as a migrant's legal status" (Hernandez, 2008; Kosse \& Vermeulen, 2014; Siegel \& Lücke, 2009). 
Willis (2011), in her paper "on the fallacy of financial education has postulated the idea of financial education as enhancing this autonomy of a person" in addressing "his or her own personal finances is a fallacy". Based on the study of Willis (2011) "education programs would need to decide what lessons to teach against a background" resulting to "lack technical and normative consensus on what constitutes correct financial behavior."

Based on a recent "study of CARD Bank clients in the Philippines, Fiorillo, Potok, Wright, Peachey, and Davies (2014) found that goal setting and frequent reminders made clients much more committed to savings" in which it revealed that "bank clients in the treatment group-that is, those that received regular text messaging reminders to save, a savings plan, and a savings calendar-made small but frequent deposits rather than those who were in the control group". Additionally, "bank clients, during their center meetings, often talked about their daily financial matters but not savings towards goals or potential".

\section{METHODOLOGY}

The researcher employed descriptive, comparative research using a mixed method - partly quantitative and qualitative in order to address the statement of the problem. In "descriptive research, it involves collecting information through data review, surveys, interviews, and observation" subjected for a data analysis (Kosse \& Vermeulen, 2014). The researcher used a survey questionnaire and interview schedule in obtaining information relevant to this study. Primary data were provided by the OFTs who are legally teaching in Thailand for at least one year. Secondary financial and non-financial data were also utilized from the "Philippine Statistics Authority, 2017 Survey on Overseas Filipinos".

A quasi-experimental pre-post quantitative design was used, and then facilitated a focus group discussion to address the qualitative research part. The quantitative, non-experimental design of inquiry was used, specifically descriptive correlational and descriptive comparative research. Correlational study comprises of data collected to "determine how related are two or more variables". When "the variables are highly related, a correlation coefficient near +1.00 is obtained meaning the variables are positively related". When "the two variables are not related, a correlation coefficient near .00 is obtained" and when "the coefficient is near -1.00 , the variable is inversely related" (Kosse \& Vermeulen, 2014). This methodology provides us information on the initial link between variables of interest (Cooray \& Mallick, 2013). In a "comparative research, there is an at- tempt to identify a cause-effect relationship between two or more groups. It involves comparison in contrast to correlations research which looks at relationships" (Kosse \& Vermeulen, 2014).

The eligibility criteria to be considered for the 53 sample are that the respondents are currently working for at least one year in the Kingdom of Thailand. Initially, there were 120 plus respondents. However, because some respondents are out of scope and demilited from the study, only 53 were qualified as research participants. Before the study was conducted, validation experts conformed to the instrument. Then, there was an approval from the validators to perform the study provided that the instrument was improved based on validators comment. A pilot test was conducted within the area of the study and the respondents during the pilot testing were not being included in the actual collection of data. The researcher facilitated the data gathering personally with research assistants. The questionnaires were collected on the same day it was given and the result were tallied and submitted to a statistician for data interpretation. The data collected and analyzed using "Frequency and Percentage Distribution".

\section{RESULTS}

One of the momentous findings in this study is the significant switch of OFTs just recently in terms of their preferred remittance service providers. Ria remittance becomes the most preferred remittance agent of OFTs. Ria, a money transfer company has recently partnered with the GSB in the Kingdom of Thailand. Ria offers a cost savings of more than 50\% compared to prominent remittance agents such as the WU. It only charges $\mathbf{B 1 5 0 . 0 0}$ per transaction. Further study may deal on the threats faced by WU and other remittance agents resulting to the partnership of Ria Remittance with the Savings Bank (GSB).

As shown in Table 1, the Philippines has a total cash remittance of $146,823,000,000$ pesos or this is (US $\$ 2,936,460,000$ assuming an exchange rate of US $\$ 1.00$ $=$ P50.00) for 2017. Out of this total cash remittance to the Philippines, $15.5 \%$ is from the Southeast Asia where Thailand belongs. The highest remittance comes from the East Asia with 23, 868,000,000 pesos or US $\$ 477,360,000$ (with Hongkong as the highest from this area with 7,125,000,000 pesos or US $\$ 142,500,000)$. Hongkong is one of the most deployed destinations for Domestic Helpers from the Philippines.

Table 1 also shows $71.4 \%$ of these remittances are coming from male OFWs which is $88,622,000,000$ pesos (US $\$ 1,772,440.00$ ) while female overseas work- 
ers have cash remittances of $58,201,000,000$ pesos (US $\$ 1,164,020,000$ ). In the Southeast and South Central Asia where Thailand belongs, male OFWs remitted $12,683,000,000$ pesos while female OFWs only remitted $5,080,000,000$ pesos. This means that male OFWs remitted more than double than what female OFWs have remitted. This could be because in the Philippines, male households (the husband/the father) are expected to provide financial assistance to the family.

TABLE 1. Total and average cash remittance of male and female overseas Filipino workers during six months prior to survey by place of work: 2017

\begin{tabular}{|c|c|c|c|c|c|c|}
\hline \multirow[t]{2}{*}{ Place of Work } & \multicolumn{3}{|c|}{ Total cash remittance (In million pesos) } & \multicolumn{3}{|c|}{ Average Cash remittance per OFW (In thousand pesos) } \\
\hline & Both Sexes & Male & Female & Both Sexes & Male & Female \\
\hline Philippines & 146,823 & 88,622 & 58,201 & 74 & 96 & 54 \\
\hline Africa & 2,207 & 2,103 & 104 & 91 & 91 & 109 \\
\hline Asia & 114,361 & 62,032 & 52,330 & 67 & 87 & 53 \\
\hline East Asia & 23,868 & 12,011 & 11,857 & 64 & 86 & 51 \\
\hline Hong Kong & 7,125 & 674 & 6,450 & 53 & 119 & 50 \\
\hline Japan & 7,917 & 5,865 & 2,052 & 86 & 102 & 59 \\
\hline Taiwan & 3,487 & 1,218 & 2,268 & 50 & 47 & 51 \\
\hline $\begin{array}{l}\text { Other countries in East Asia (includ- } \\
\text { ing China and South Korea) }\end{array}$ & 5,340 & 4,253 & 1,087 & 73 & 84 & 47 \\
\hline Southeast and South Central Asia & 17,763 & 12,683 & 5,080 & 95 & 156 & 48 \\
\hline Malaysia & 1,332 & 634 & 697 & 44 & 54 & 37 \\
\hline Singapore & 11,545 & 8,605 & 2,940 & 109 & 223 & 44 \\
\hline $\begin{array}{l}\text { Other countries in Southeast and } \\
\text { South Central Asia (including } \\
\text { Thailand, Brunei, Cambodia and } \\
\text { Indonesia)* }\end{array}$ & 4,886 & 3,443 & 1,442 & 96 & 112 & 71 \\
\hline Western Asia & 72,730 & 37,338 & 35,393 & 63 & 76 & 54 \\
\hline Kuwait & 7,062 & 2,195 & 4,867 & 50 & 84 & 43 \\
\hline Qatar & 6,325 & 3,924 & 2,402 & 60 & 73 & 46 \\
\hline Saudi Arabia & 34,165 & 20,529 & 13,637 & 67 & 75 & 57 \\
\hline United Arab Emirates & 19,653 & 8,536 & 11,117 & 64 & 73 & 58 \\
\hline $\begin{array}{l}\text { Other countries in Western Asia } \\
\text { (Bahrain, Israel, Lebanon and Jordan) }\end{array}$ & 5,524 & 2,154 & 3,370 & 64 & 93 & 53 \\
\hline Australia & 3,550 & 2,777 & 773 & 110 & 118 & 87 \\
\hline Europe & 14,426 & 11,847 & 2,578 & 118 & 136 & 74 \\
\hline North and South America & 12,279 & 9,863 & 2,416 & 114 & 133 & 72 \\
\hline
\end{tabular}

"Source: Philippine Statistics Authority, 2017 Survey on Overseas Filipinos"

"Notes: Details may not add up to totals due to rounding". "The estimates cover remittances during six months prior to survey of overseas Filipinos whose departure oc- curred within the last five years and who are working or had worked abroad during the past six months (April to September) of the survey period".

TABLE 2. Monthly income of OFTs in the kingdom of Thailand

\begin{tabular}{llll}
\hline \hline Monthly Income (in baht) & $\begin{array}{l}\text { Monthly Income (in pesos) Assuming } \\
\text { an exchange rate of B1.00 = P1.65 }\end{array}$ & Frequency & Percentage \\
\hline B35,000C above & P57,750.00 above & 1 & \\
B30,001 - B35,000 & P 49,501.65 - P57,750.00 & 4 & 7.89 \\
B25,001 - B30,000 & P 41,256.60 - P 49,500.00 & 14 & 26.52 \\
B20,001- B25,000 & P 33,001.65 - P 41,250.00 & 23 & 43.40 \\
B15,001 - B20,000 & P 24,751.65 - P 33,000.00 & 9 & 16.98 \\
B10,000- B15,000 & P 16,500.00 - P 24,750.00 & 53 & 3.77 \\
& Total & 53 & 100.00 \\
\hline \hline
\end{tabular}

"Source: Philippine Statistics Authority, 2017 Survey on Overseas Filipinos" 
In Table 2 above, it shows that majority (69.82\%) of the OFTs in Thailand have monthly income ranging $\$ 20,000$ to $\mathrm{B} 30,000$ or $\mathrm{P} 33,000.00$ to $\mathrm{P} 49,500.00$ because is double to earnings received by those working in the Philippines whose earnings are subject to an estimated 30\% tax. However, there is still significant number of OFTs (16.98\%) whose earnings are below $\$ 20,000$. This is very disap- pointing because this is the same earnings to those teachers working in the Philippines. So, why work in Thailand when you earn same salary in the Philippines? Some OFTs have part-time tutorial jobs to compensate their salary. Some OFTs are using their Thailand teaching experience as a stepping stone to teach in Western countries offering a more than double salary than in the Kingdom of Thailand.

TABLE 3. Total and average cash remittance of overseas Filipino workers during six months prior to survey by mode of remittance and area: 2017

\begin{tabular}{|c|c|c|c|c|c|c|}
\hline Area & Total & Banks & $\begin{array}{l}\text { Agency and or } \\
\text { Local Office }\end{array}$ & $\begin{array}{l}\text { Friends and or } \\
\text { Co-workers }\end{array}$ & Door-to- Door & Others \\
\hline \multicolumn{7}{|l|}{ Philippines } \\
\hline Total cash remittance (In million pesos) & 146,823 & 92,243 & 4,608 & 162 & 1,215 & 48,596 \\
\hline $\begin{array}{l}\text { Average cash remittance per OFW (In } \\
\text { thousand pesos) }\end{array}$ & 74 & 93 & 91 & 22 & 66 & 52 \\
\hline
\end{tabular}

"Source: Philippine Statistics Authority, 2017 Survey on Overseas Filipinos"

"Note: The estimates cover remittances during six months prior to survey of overseas Filipinos whose departure occurred within the last five years and who are working or had worked abroad during the past six months (April to September) of the survey period".

Based on the data from the Philippine Statistics Authority in 2017 survey of Overseas Filipino Workers and as shown in table 3 , it can be seen that $92,243,000,000$ pesos ( US $\$ 1,844,860,000$ assuming an exchange rate of US $\$ 1.00=$ P50.00) out of $146,823,000,000$ pesos (US $\$ 2,936,460,000$ ) or $62.83 \%$ of total cash remittances were remitted thru banks. This means that banks are the most trusted remittance service provider by the OFWs. Thus, the "top global remittance service providers such as Western Union, Ria, and Money Gram" have partnered with banks. However, these remittance service providers have limited service. They can only offer remittance service to individual recepients. Based on the interview with banks in Thailand, only Bangkok Bank offers remittance deposit to non-personal deposits such as company deposits the charge is very expensive. Bangkok Bank charges 1,100 baht which is more than five times more expensive than Ria remittance.

TABLE 4. Distributions of overseas Filipino workers with savings from cash remittances by percentage of cash remittance set aside for savings: 2017

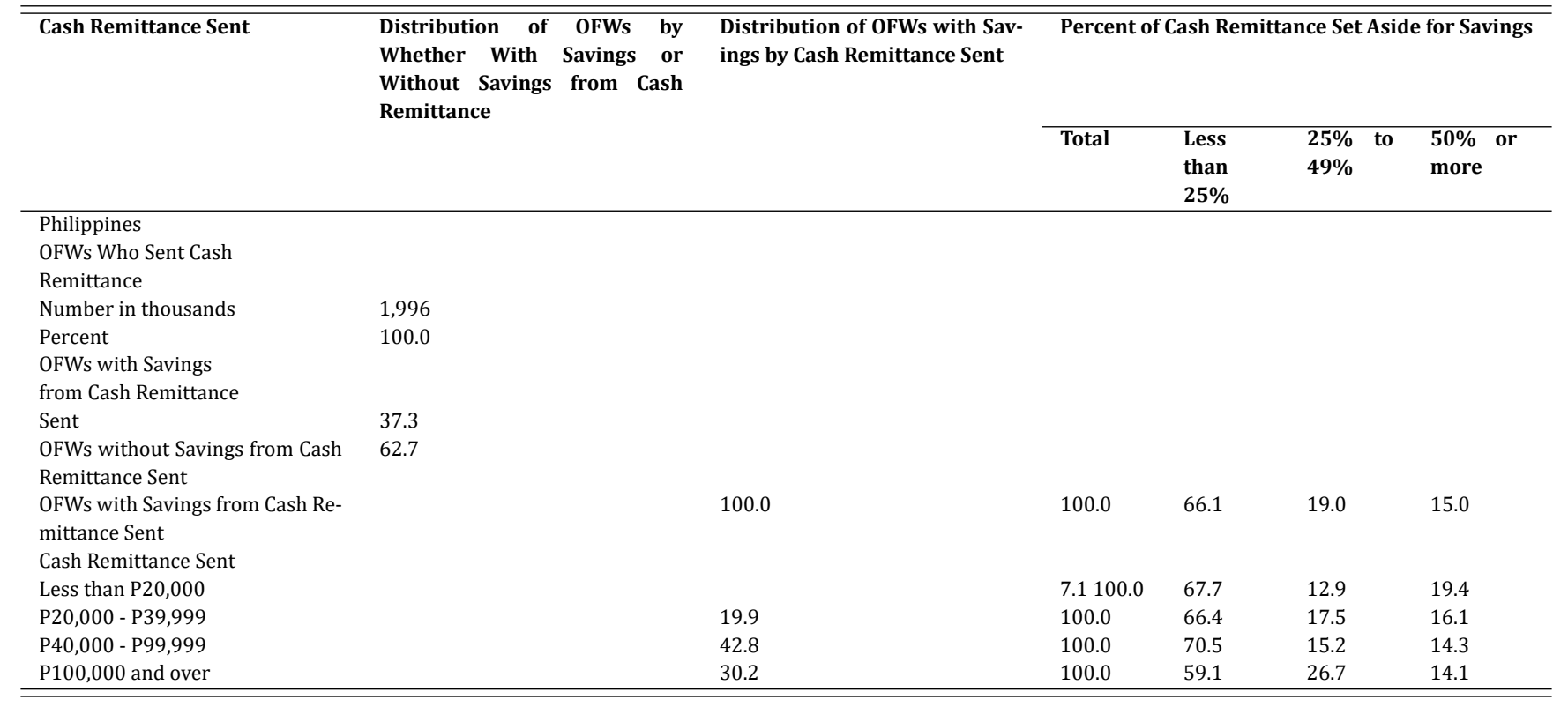

"Source: Philippine Statistics Authority, 2017 Survey on Overseas Filipinos" 
"Note: The estimates cover overseas Filipinos who sent cash remittances during six months prior to survey, and whose families were able to set aside for savings".

It could be seen in the table above that only $37.3 \%$ (or $1,996,000$ pesos) OFWs have allotted for savings from cash remittance they sent to the Philippines. Sixty-three percent of OFWs do not have savings from cash remittances sent. In addition, those with savings only allot less than $25 \%$ of their cash remittances which $66.1 \%$ of the OFWs. Table 4 shows that almost half of the OFWs (42.8\%) have cash remittances sent to the Philippines ranging from P40, 000 $\mathrm{P} 99,999$. This amount is more than enough for a monthly of their families back in the Philippines. However, most recipient of the cash remittances spend to nonsense expenditure items instead of allotting savings and establishing a startup business.

TABLE 5. Monthly cash remittances of OFTs in the kingdom of Thailand

\begin{tabular}{llll}
\hline \hline Monthly Remittance (in baht) & $\begin{array}{l}\text { Monthly Remittance (in pesos) Assuming } \\
\text { an exchange rate of B1.00 = P1.65 }\end{array}$ & Frequency & Percentage \\
\hline B20,000 above & P 33,000.00 above & 2 & 3.77 \\
B15,001 - B20,000 & P24,751.65 - P 33,000.00 & 1 & 1.89 \\
B10,001- B15,000 & P16,501.65 - P 24,750.00 & 25 & 47.17 \\
B5,001- B10,000 & P8,251.65 - P 16,500.00 & 16 & 30.19 \\
B1,001 - B5,000 & P1,651.65 - P 8,250.00 & 8 & 15.09 \\
B1,000 and below & P 1,650.00 and below & 1 & 1.89 \\
& Total & 53 & 100.00 \\
\hline \hline
\end{tabular}

Studies have found "that remittances are positively correlated with income in the recipient countries (Giuliano and Ruiz-Arranz 2009, (Cooray \& Mallick, 2013; Giuliano \& Ruiz-Arranz, 2009; Sayan, 2006). As shown in Table 6, cash remittances of almost $80 \%$ of the OFTs in the Kingdom of Thailand range from $\mathrm{B} 5,000$ to $\mathrm{B} 15,000$ or $\mathrm{P} 8,250.00$ to $\mathrm{P}$ $24,750.00$. This is roughly $25 \%$ of their monthly salary.
Unfortunately, there is a significant number of OFTs (roughly $17 \%$ ) who can only remit below $\$ 5,000$ or $\mathrm{P}$ $8,250.00$ assuming an exchange rate of $\mathrm{B} 1.00=\mathrm{P} 1.65$. This is not enough amount for a monthly family expense. These OFTs are suggested to either just work in the Philippines or augment their income by having part-time tutorial jobs.

TABLE 6. Aggregate remittance cost comparisons among top service providers

\begin{tabular}{|c|c|c|c|c|}
\hline \multirow[t]{2}{*}{ Remittance Service Providers } & \multirow[t]{2}{*}{ Charge } & \multirow[t]{2}{*}{ Exchange Rate } & \multicolumn{2}{|c|}{ Total Cash Remittance } \\
\hline & & & (at $\mathrm{B} 5,000 \mathrm{~min}$ ) & (atB 15,000 min) \\
\hline $\begin{array}{l}\text { Ria (owned by Euronet) (in part- } \\
\text { nership with Government Savings } \\
\text { Bank in Thailand) }\end{array}$ & $\begin{array}{l}\text { \$150.00 (fixed regardless of the } \\
\text { remittance amount) }\end{array}$ & B1.00 = P1.65 & P 8,250.00 & P $24,750.00$ \\
\hline \multirow[t]{2}{*}{ Western Union } & B475.00 & & & \\
\hline & $(B 2,500.01-B 20,000.00)$ & $\mathrm{B} 1.00=\mathrm{P} 1.60$ & $P 8,000.00$ & P 24,000.00 \\
\hline \multirow[t]{2}{*}{ Money Gram } & B150.00 & & & \\
\hline & $\begin{array}{l}\text { (fixed regardless of the remit- } \\
\text { tance amount) }\end{array}$ & $\mathrm{B} 1.00=\mathrm{P} 1.59$ & P 7,950.00 & P $23,850.00$ \\
\hline
\end{tabular}

Table 6 shows the comparative analysis in terms of the aggregate remittance cost among top global remittance service providers. Ria is the most cost-efficient remittance provider because it provides the lowest aggregate cost but the highest exchange rate. The second choice is Money Gram because it will a cost savings of P523.53 compared to Western Union which has the highest remittance cost. As shown in Table 7, settling loans from lending institutions has the highest allocation in the cash remittances sent by OFTs in their first year of teaching in the Kingdom Thailand. The second highest allocation in their first year abroad is allotted for tuition fee of their children pursuing law and medicine followed by the purchase of gadgets. In the second of teaching abroad and after settling their loans, OFTs still have the highest allocation for tuition fee of their children. 
TABLE 7. Cash remittance allocation in the first two years of teaching abroad

\begin{tabular}{lll}
\hline \hline Expenditure Items from Cash Remittance & \multicolumn{2}{c}{ Allocation (\% of Remittance) } \\
\cline { 2 - 3 } & First Year & Second Year \\
\hline Settle loan from lending institutions & 39.6 & 9.4 \\
Tuition fee of children pursuing law and medicine & 26.4 & 30.2 \\
Buy gadgets such as smart phones, laptop computers, and digital cameras & 20.8 & 26.4 \\
Investment in house and lot & 5.7 & 11.3 \\
Home appliances and home improvements & 3.8 & 18.9 \\
Vacation and leisure & 1.9 & 1.9 \\
Savings & 1.9 & 1.9 \\
\hline \hline
\end{tabular}

However, what is disappointing here is that they always buy gadgets and prioritize purchase of home appliances and home improvements but with zero to very minimum allocation for savings, investment in long-term assets like land and the worst thing is these OFTs don't normally enjoy themselves by going on a vacation to a new country.

\section{DISCUSSION AND CONCLUSION}

Aggregate cost of sending money to the Philippines ranges from B150 to B475 per transaction depending on the remittance service provider. Based on this study, it shows that Ria Remittance Service Provider is the best choice because it offers the lowest aggregate cost but with the highest exchange rate favorable to the receiving country, the Philippines.

It is good that the Philippine has remittance programs for OFWs. Nicolas and Rodriguez (2019) noted that "Remittance for Development Council which was established in 2012 by the Commission on Filipinos Overseas the Central Bank of the Philippines" which serves "as a forum for regular dialogue on remittance issues which include lowering of remittance costs, democratization of remittance channels, innovation in remittance services like the use of e-cash, advocating for increased financial education of migrants and their families".

\section{Recommendations \& Implications}

It is highly recommended to conduct "financial literacy programs on-site at the migrants' destination countries can also be beneficial, since (i) it inculcates in them importanthabits about financial management while they are earning, and (ii) it can develop in them information-seeking behavior as they would most likely seek more information as to how their recipients are using the remittances" to significantly improve the finances of the OFWs. This study suggests formation of Thailand Network of Filipino Diaspora to provide a platform for overseas Filipinos to come together and become partners for development both socially and financially. Philippine banks should be encouraged to offer wire transfer. For instance, "Philippine National Bank charges fewer fees when wire transfers done with ATM cards linked with foreign partner banks" similar to the partnership between and the Government Savings Bank.

Additionally, it is recommended to integrate "financial education into the school curricula wherein if compared with the US where financial education is part of the school curricula of many states, financial education is not yet integrated into school curricula in many countries in Asia" particularly in the Southeast Asia. Whereas "national strategies for financial inclusion implemented by the Philippines and Indonesia, for example, underscore the importance of having financial education classes at the elementary and high school levels, financial literacy and inclusion still remains relatively low" thus there is a need to improve on the level of financial literacy education.

\section{REFERENCES}

Agcaoili, L. (2016). BSP encourages more bank mergers: The Philippine star. Retrieved from https://bit. 1y/2B1yDPi (accessed 9 January, 2018)

Ahsan, A. (2014). International migration and development in East Asia and the Pacific. Washington, DC, WA: World Bank. Ashraf, N., Aycinena, D., Claudia, M. A., \& Yang, D. (2015). Savings in transnational households: A field experiment among migrants from El Salvador. Review of Economics and Statistics, 97(2), 332-351. doi:https://doi.org/10.1162/rest_a -00462

Asis, D. (2010). Bayanihan foundation worldwide. Retrieved from https://bit.1y/2FYCjVy (accessed 10 May, 2018)

Bettin, G., Lucchetti, R., \& Zazzaro, A. (2012). Endogeneity and sample selection in a model for remittances. Journal of Development Economics, 99(2), 370-384. doi:https://doi.org/10.1016/j.jdeveco.2012.05.001

Cebeci, I. (2016). Istanbul's position as a financial center: An empirical analysis. International Journal of Business and Economic Affairs, 1(1), 1-5. doi:https://doi.org/10.24088/ijbea-2016-11001 
Cooray, A., \& Mallick, D. (2013). International business cycles and remittance flows. The BE Journal of Macroeconomics, 13(1), 515-547. doi:https://doi.org/10.1515/bejm-2013-0030

Doi, Y., McKenzie, D., Zia, B., et al. (2012). The impact of financial literacy training for migrants and their families (Tech. Rep.). The World Bank, Washington, D.C, WA.

Durdu, C. B., \& Sayan, S. (2010). Emerging market business cycles with remittance fluctuations. IMF Staff Papers, 57(2), 303-325. doi:https://doi.org/10.1057/imfsp.2009.3

Fiorillo, A., Potok, L., Wright, J., Peachey, J., \& Davies, K. (2014). Applying behavioral economics to improve microsavings outcomes. Retrieved from https://bit.1y/2FMDpEm (accessed 14 June, 2017)

Frankel, J. (2011). Are bilateral remittances countercyclical? Open Economies Review, 22(1), 1-16. Retrieved from https:// doi.org/10.1007/s11079-010-9184-y

Gammeltoft, P. (2002). Remittances and other financial flows to developing countries. International Migration, 40(5), 181-211. doi:https://doi.org/10.1111/1468-2435.00216

Gibson, J., McKenzie, D., \& Rohorua, H. T. S. (2006). How cost elastic are remittances? Estimates from Tongan migrants in New Zealand. Pacific Economic Bulletin, 21(1), 112-128.

Gibson, J. D., \& McKenzie, B. Z. (2012). The impact of financial literacy training for migrants (Working paper no. 6073). The World Bank, Washington, DC, WA.

Giuliano, P., \& Ruiz-Arranz, M. (2009). Remittances, financial development, and growth. Journal of Development Economics, 90(1), 144-152. doi:https://doi.org/10.1016/j.jdeveco.2008.10.005

Hernandez, C. R. (2008). The Malaysia-Indonesia remittance corridor: Making formal transfers the best options for women and undocumented migrants (Working paper no. 149). World Bank, Washington, DC: WA.

Hoai, N. N., \& Thanwadee, H. (2015). Investigating factors influencing profits enhancement in real estate companies in Ho Chi Minh City, Viet Nam. International Journal of Business and Administrative Studies, 1(3), 107-113. doi:https://doi.org/ 10.20469/ijbas.10005-3

Kaplan, H. R. (2011). The myth of post-racial America: Searching for equality in the age of materialism. New York, NY: R\&L Education.

Kefela, G. (2011). Implications of financial literacy in developing countries. African Journal of Business Management, 5(9), 3699-3705.

Kosse, A., \& Vermeulen, R. (2014). Migrant's choice of remittance channel: Do general payment habits play a role? (Working paper no. 1683). Frankfurt: European Central Bank, Frankfurt, Germany.

Lueth, E., \& Ruiz-Arranz, M. (2008). Determinants of bilateral remittance flows. The BE Journal of Macroeconomics, 8(1), 12-40. doi:https://doi.org/10.2202/1935-1690.1568

Nicolas, I. M., \& Rodriguez, J. L. S. (2019). The Philippines experience in managing diaspora resources: Policies and initiatives in facilitating diaspora engagement. In Elo M., Minto-Coy I. (ED.,), Diaspora networks in international business. New York, NY: Springer.

Sayan, S. (2006). Business cycles and worker's remittances: How do migrant workers respond to cyclical movements of GDP at home? (Working paper no. 06/52). International Monetary Fund, Washington, DC, WA.

Siegel, M., \& Lücke, M. (2009). What determines the choice of transfer channel for migrant remittances? the case of Moldova (Unpublished master's thesis). Maastricht University, Maastricht, Netherlands.

United States Department of States. (2017). Trafficking in persons report 207. Retrieved from https://bit. ly/2w1Lih8 (accessed 16 July, 2018)

Willis, L. E. (2011). The financial education fallacy. American Economic Review, 101(3), 429-34. doi:https://doi.org/ 10.1257/aer.101.3.429

World Bank Report. (2015). Global economic prospects. Retrieved from https://bit.1y/2idZrB2 (accessed 15 July, 2017)

Yoo, J., Lee, M. K., \& Lee, W. S. (2016). Asymmetrical corporate responses to economic information: Applying the firm size effect. Journal of Administrative and Business Studies, 2(1), 29-34. doi:https://doi.org/10.20474/jabs-2.1.4 